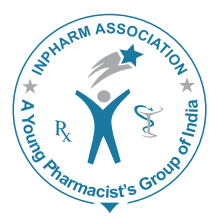

\title{
The affect of mentoring on academic achievement in a child with attention-deficit hyperactivity disorder: Case study
}

\author{
Muaed Jamal Alomar ${ }^{1 *}$, Claire Caroline Strauch² \\ ${ }^{1}$ Department of Clinical Pharmacy, Alain University of Science and Technology, UAE, ${ }^{2}$ English Department, \\ Liwa International School, Alain, UAE
}

\begin{abstract}
Attention-deficit hyperactivity disorder (ADHD) is a syndrome of hyperactivity, inattention, and impulsivity. ADHD is defined as a neurobehavioral developmental disorder, which is characterized by the presence of both attention problems and hyperactivity. Sources have estimated that ADHD affects approximately $5-15 \%$ of school aged children. Unfortunately, traditional classrooms and academic activities often make the symptoms and signs worse in children with untreated or improperly treated ADHD. There may be persistent social and emotional adjustment problems. With an increase in age and the obvious display of symptoms, children are often poorly accepted by peers and loneliness and isolation increases. Child A was a hyperactive student prone to sudden outbursts in class exacerbated by a lack of attention. This behavior needed rectifying, and techniques used were seating the student in close proximity to the teacher, rewarding appropriate behavior and showing the student how to gain other's attention appropriately. He was also given one-to-one mentoring sessions with his teacher in order to encourage the child and to determine any problems or issues he had and then attempt to rectify them. These techniques when used with Child A showed positive effects in improving his overall behavior. Child A was not receiving any medications, so the mentoring sessions alone can be credited with his improved behavior and performance. ADHD can have serious affects on a child's social and academic development. There is a serious need for intervention in order to try to overcome these developmental obstacles. Further study, involving the use of other cognitivebehavioral techniques is recommended.
\end{abstract}

Key words: Attention-deficit hyperactivity disorder, behavioral, child, cognitive therapy, hyperactivity

\section{INTRODUCTION}

Attention-deficit hyperactivity disorder (ADHD) is a syndrome of hyperactivity, inattention and impulsivity.

\begin{tabular}{|c|c|}
\hline \multicolumn{2}{|c|}{ Access this article online } \\
\hline Journal Sponsor & \multirow[b]{2}{*}{$\begin{array}{l}\text { Website: } \\
\text { www.jyoungpharm.org }\end{array}$} \\
\hline \multirow{2}{*}{ www.phcog net } & \\
\hline & $\begin{array}{l}\text { DOI: } \\
\text { 10.5530/jyp.2014.2.11 }\end{array}$ \\
\hline
\end{tabular}

ADHD is defined as a neurobehavioral developmental disorder, which is characterized by the presence of both attention problems and hyperactivity. ${ }^{1}$

Approximately, 20-60\% of children with ADHD experience learning disabilities; however, some degree of school dysfunction also occurs in most children with ADHD. Research has shown that approximately one-third of children with ADHD have some degree of learning disabilities. ${ }^{2}$ It is also evident that the behavioral history of a child can show a low frustration tolerance, aggressiveness, opposition, temper tantrums, poor social skills, and peer relationships. ${ }^{3}$

*Address for correspondence:

Dr. Muaed Jamal Alomar, Department of the Clinical Pharmacy, Alain University of Science and Technology, P.O. Box 222319, UAE.

E-mail: muayyad74@yahoo.com 
The aim of this case report is to determine what methods and techniques of mentoring have been shown to have positive effects on the outcome of academic underachievement in children suffering from ADHD.

\section{CASE REPORT}

Child A was a hyperactive student; prone to outbursts in the classroom. His disruptive behavior included walking around the classroom during lessons, shouting out answers before being called on, answering in place of other children, refusing to do his work or write in class; if disciplined in any manner he would pout and behave in a spoilt manner. One of his favorite expressions was "I don't want to". On one occasion, the lesson was to be videoed as the teacher, dressed as a character from a book, read to the children. The rest of the class was listening intently, and Child A suddenly stood up and shouted "I am a tiger!" The behavior observed in the classes had also been reported to the register class teacher by his other subject teachers, most commonly scribbling instead of writing or refusing to write at all. This behavior needed rectifying, and techniques used included those recommended by Rief (2005), such as seating the student in close proximity to the teacher, rewarding appropriate behavior and showing the student how to gain other's attention appropriately. These techniques when used with Child A have shown positive effects in improving his overall behavior.

\section{DISCUSSION}

We used the mentoring sessions as an opportunity to listen to the child and find ways to positively motivate him. Some researchers have shown that by paying close attention to students who are considered "at risk" teachers can enhance student achievement through perseverance. ${ }^{4}$ We decided in order to motivate him, we needed to focus on paying him extra attention, as he seemed to crave individual attention. Furthermore, rather than dismissing work, which was not part of the lesson, encouraging it and expanding on it.

Studies have recommended that teachers can include rigor, thought, diversity and authenticity in the classroom as a means of increasing student achievement. When used in the case of Child A it was shown to be particularly useful as the child gets bored quickly. ${ }^{5}$

Child A had stated in one session that he liked English, but his hands got tired when writing for a long time. The teacher was pleasantly surprised that he had given her a reason for his behavior and immediately offered him a solution to try. The teacher suggested he try various hand exercises to try to strengthen his fingers and hands. He enthusiastically tried them, and later told his teacher in class he was practicing them at home. The teacher was pleased at the positive response from him. This also showed a positive outcome from the one-to-one mentoring sessions.

At our request a parent-teacher meeting was held between us and the child's register class teacher and the child's mother. The purpose of this meeting was to determine if there were any underlying issues at home, which might be responsible for his behavior in class. Mentoring relationships have been associated with improvements in academic performance, school attendance and a positive self-satisfaction. ${ }^{6}$ Thus, we felt the need for such mentoring sessions to be essential to Child A's development.

In response to our meeting with the child's mother, we felt it was necessary to initiate one-on-one mentoring sessions with the child. In an attempt to start a mentoring program in the form of a school based program the teacher set aside time periods where Child A would be able to come and speak with her.

One of the main aim of the mentoring sessions were to gain the child's trust, which would help him to open up about any problems he might be having regarding the lessons and to create a friendly environment in which he would feel comfortable enough to discuss any issues that may be bothering him. The child felt able to confide in us about his wish to attend karate lessons, which supports the idea of being able to open up when feeling comfortable. We also needed to determine if there were any factors at home contributing to his misbehavior in class which we might be able to discuss. His position is his family as the only boy who seemed to be favored could have also been a contributing factor to his behavior. When used in conjunction with medication; the use of behavioral therapy as a means of reducing ADHD symptoms has been shown to be more effective than medicating alone. ${ }^{7,8}$ Currently, Child $\mathrm{A}$ is not receiving any medications, so the mentoring sessions alone can be credited with his improved behavior and performance.

\section{CONCLUSION}

ADHD can have serious affects on a child's social and academic development. There is a serious need for intervention in order to try to overcome these developmental obstacles. Research discussed earlier has 
shown that this can be achieved by various means, such as medication and behavioral therapy. The use of various mentoring techniques, such as the GROW model and positive reinforcement produced favorable results in this case. Child A is not receiving any medication, but seemed to respond very positively to behavioral therapy, in the form of mentoring sessions with his English teacher and classroom motivational techniques.

\section{REFERENCES}

1. Schwarz SC, Rhodes JE, Herrera, C. The influence of meeting time on academic outcomes in school-based mentoring. Child Youth Serv Rev 2012;34:2319-26.

2. Espiner D, Guild D. Capturing what matters most; engaging students and their families in educational planning. Teach Except Child 2012;44:56-67.
3. Barkley RA. Attention Deficit Hyperactivity Disorder: A Handbook for Diagnosis and Treatment. $3^{\text {rd }}$ ed. New York: Guilford Press; 2006.

4. Gray L, Park JJ, Msall ME. Children and adolescents with ADHD: Risk and protective factors for addictive disorders. In: Miller N, Gold MS, editors. Addictive Disorders in Medical Populations. Ch. 30. West Sussex: John Wiley and Sons Ltd.; 2010.

5. Biederman J, Petty CR, Fried R, Wozniak J, Micco JA, Henin A, et al. Child behavior checklist clinical scales discriminate referred youth with autism spectrum disorder: A preliminary study. J Dev Behav Pediatr 2010; 31:485-90

6. Murray J, McNamara O, Jones M. Improving workplace learning in teacher education. In: Workplace Learning in Teacher Education. Vol. 10. Netherlands: Springer; 2014. p. 293-315.

7. Biederman J, Petty CR, Evans M, Small J, Faraone SV. How persistent is ADHD? A controlled 10-year follow-up study of boys with ADHD. Psychiatry Res 2010;177:299-304.

8. Corkum P, McGonnell M, Schachar R. Factors affecting academic achievement in children with ADHD. J Appl Res Learn 2010;3:1-14. 